\title{
Lumen
}

Selected Proceedings from the Canadian Society for Eighteenth-Century Studies

\section{Starry Wheels and Watch-Fiends: Clocks and Timepieces in William Blake's Milton}

\section{Grant Campbell}

Volume 17, 1998

Theatre of the world

Théâtre du monde

URI : https://id.erudit.org/iderudit/1012387ar

DOI : https://doi.org/10.7202/1012387ar

Aller au sommaire du numéro

Éditeur(s)

Canadian Society for Eighteenth-Century Studies / Société canadienne d'étude du dix-huitième siècle

ISSN

1209-3696 (imprimé)

1927-8284 (numérique)

Découvrir la revue

Citer cet article

Campbell, G. (1998). Starry Wheels and Watch-Fiends: Clocks and Timepieces in William Blake's Milton. Lumen, 17, 165-174. https://doi.org/10.7202/1012387ar

Copyright (c) Canadian Society for Eighteenth-Century Studies / Sociéte canadienne d'étude du dix-huitième siècle, 1998
Ce document est protégé par la loi sur le droit d'auteur. L'utilisation des services d'Érudit (y compris la reproduction) est assujettie à sa politique d'utilisation que vous pouvez consulter en ligne.

https://apropos.erudit.org/fr/usagers/politique-dutilisation/ 


\section{Starry Wheels and Watch-Fiends: Clocks and Timepieces in William Blake's Milton}

The relationship between literary texts and technological development in the eighteenth century is a complex one, which defies the boundaries of ideology and formal statements of conviction. Certainly, Blake and the great horologists of the eighteenth century make strange bedfellows, and I should clarify at the outset that this study explores not a perceived influence but a perceived resemblance. It does not suggest that Blake was covertly influenced by the British horological revolution of 1660-1760; rather, it suggests that both the remarkable horological inventions of John Harrison, Thomas Mudge and others, and the remarkable poetical inventions of Blake arose from a common conceptual source.

Joel Black has suggested that the significance of Romanticism in the history of science lies in the way it anticipated future questioning of modern science's epistemological assumptions. For Black, the Romantic authors were 'forerunners of today's Poppers, Kuhns, Feyerabends ... and the present breed of historians and philosophers who have exposed the progressivist, gradualist, functionalist, and positivist biases of modern science and who have subjected such naive notions as scientific objectivity and verifiability to rigorous scrutiny. ${ }^{1}$ However, the Romantics' scrutiny of scientific principles was anticipated by an earlier group of creators: the great English horologists of the eighteenth century, whose inventions changed the nature of navigation and maritime commerce, in spite of opposition from the dominant scientific voices of the day. Both Blake and the horologists, despite their ideological differences, drew upon a common paradox: a perceived tension between the great and the minute, between a broad perspective that encompasses astronomical motion and an eye for detail on the most minute level. Furthermore, I would suggest that both Blake and the horologists were only able to negotiate this paradox by escaping from the shadow of Newton and the perspectives of Deism. This resemblance, however, has been clouded by the fact that the horologists were busily perfecting a clockwork mechanism that served as the primary metaphor for an ideology which Blake abhorred. 
Time is a fundamental concept in Blake's elaborate cosmology, and he made no secret of his distrust of clockwork movement as a means of conceptualizing it. 'The hours of folly are measur'd by the clock,' he announces in The Marriage of Heaven and Hell, 'but of wisdom: no clock can measure. ${ }^{2}$ Northrop Frye, in Fearful Symmetry, suggests that for Blake, clock time represents the tyranny of sequence:

Clock time [for Blake] is a mental nightmare like all other abstract ideas. An impalpable present vanishing between an irrevocable past and an unknown future, it is the source of all our ideas of fate and causality. It suggests an inexorable march of inevitably succeeding events in which everything is a necessary consequence of cause stretching back to an unknown God as a First Cause and stretching on into a future which would be completely predictable if it were not too complicated. Its only possible symbol not only for Blake but even for those who believe in it is the chain, which is also a symbol of slavery. ${ }^{3}$

Samuel Macey, in Clocks and the Cosmos, detects in Blake's writings a general Romantic distaste for mechanistic conceptions of time, and a nostalgia for more primitive forms of timekeeping, such as the sundial, which seemed more integrated with the natural rhythms of night and day. In his analysis, the Romantic imagination perceived the clock as an image of an outmoded and sterile philosophical system: 'The same clockwork which ... had symbolized the order needed by theologians, philosophers and poets alike was now becoming ... a symbol of the devil rather than of God. ${ }^{4}$

It is important to note, however, that timepieces and mechanisms for measuring time are not an isolated feature of Blake's system. The clock occupies a place in a broader class of images, in which the wheel, the factory, the mill and the chain coexist with the clock along a continuum, producing a collective image of mechanical, repetitious movement which is at odds with Blake's conception of poetic or prophetic vision. 'The bounded is loathed by its possessor,' claims Blake in There Is No Natural Religion (1788); 'The same dull round even of a universe would soon become a mill with complicated wheels. ${ }^{5}$ Satan, in Milton and elsewhere, is the 'Prince of the starry wheels.' In A Public Address, Blake condemns epigrammatic wit in art as productive simply of 'System \& Monotony,' to be avoided 'as a destructive Machine. ${ }^{\prime}$ And in the first book of Jerusalem, he provides a vision of these starry wheels as 'cogs tyrannic / Moving by compulsion each other' (15:18-19). The clock, then, occupies a place alongside the mill and the wheel in Blake's imagery, as part of a collective image of demonic, non-visionary movement.

Critics have traditionally, and rightly, associated this hostility towards clockwork movement with Blake's rejection of 'Bacon, Newton \& 
Locke,' and his hostility towards Deism and the Enlightenment. David Erdman argues that Blake, in his early poetry, associated revolution with a questioning of the Newtonian status quo, in particular its reduction of the universe to a relentless series of likenesses, obeying universal laws, and showing no variety. ${ }^{7}$ Frye, in Fearful Symmetry, argues that the Deistic notion of the 'clockwork universe' set in motion by God as a first cause produced a 'skeptical exhaustion of spirit,' associated with the ascendency of Urizen, and an over-reliance on the fallen world's concept of 'common sense,' which 'assumes the finality of the two primary categories of common sense, time and space' (320). And Donald Ault, in Visionary Physics, clarifies the simultaneous seductiveness and danger which Newton's laws of universal attraction held for Blake. Ault draws on a distinction, originally posited by Jacob Bronowski, between Newton's vision of infinite space containing finite orbits bounded by universal laws, and Blake's vision of finite space which has no bounding surfaces. He argues that Newton's cosmology is a parody of Blake's concept of poetic vision: 'Blake ... visualizes Newton's system as providing a usurpation of and substitution for the very vision he himself is trying to communicate'; Newton's mathematical vision produces nothing more than a powerful imaginative body which twists into 'a mathematical parody of itself.' Blake, Ault argues, associated Newton, with questionable validity, with the Cartesian mechanists, including Voltaire and Boyle, who posited that the universe was a 'self-sustained scheme ... sufficiently stable not to require the constant intervention of God. ${ }^{8}$ 'God is not a mathematical diagram,' wrote Blake in the margins of Berkeley's Siris. ${ }^{9}$ And the clock, with its intricate, interlocking wheels, set in motion and then left to run, provided a central metaphor during the Enlightenment for an image of a universe governed by immutable mathematical laws. ${ }^{10}$

None of this is new. However, it is important to realize that when Blake rejects 'Bacon, Locke \& Newton,' and talks of Satan's 'watchfiends,' he is not rejecting horology as a profession; nor is he necessarily rejecting the mechanical timepiece as a technological achievement. He is responding, rather, to the appropriation of the clockwork mechanism as a metaphor for a philosophy he abhors. Blake has his own conception of time, and to understand the resemblances between Blake's vision and that of the great English horologists of the eighteenth century, we need to understand Blake's conception on its own terms.

In Milton, Blake offers one of his most famous explorations of the nature of time. In this poem, Milton, dissatisfied with heaven, re-enters the physical world to be reincarnated in Blake. Book One ends with a vision in which the sons of Los 'build' time up from moments and minutes to ages and periods: 
And every Moment has a Couch of gold for soft repose, (A Moment equals a pulsation of the artery) And between every two Moments stands a Daughter of Beulah To feed the Sleepers on their Couches with maternal care. And every Minute has an azure Tent with silken Veils.

Each has its guard, each Moment Minute Hour Day Month \& Year.

All are the work of Fairy hands of the Four Elements.

The Guard are Angels of Providence on duty evermore.

Every Time less than a pulsation of the artery

Is equal in its period \& value to Six Thousand Years.

For in this Period the Poet's Work is Done: and all the Great

Events of Time start forth \& are conceived in such a Period -

Within a Moment: a Pulsation of the Artery. (28:46-62, 29:1-3)

In Book Two, Ololon's descent after Milton results in a similar vision, in which time is once again conceived as a 'moment' hidden within a demonically-ordered sequence:

There is a moment in each Day that Satan cannot find Nor can his Watch Fiends find it, but the Industrious find This Moment \& it multiply, \& when it once is found It renovates every Moment of the Day if rightly placed. (35:42-45)

Time, in the visionary, prophetic sense, constitutes a consolidation, or rejoining, of what had been separate categories of past and future, producing a moment of infinity within a finite, temporal sequence. For Frye, Blake defies the Deistic notion of a temporal sequence, to produce a vision in which 'a vertical timeless axis [crosses] the horizontal flow of time at every moment, providing in that moment a still point of a turning world, a moment in each day that Satan cannot find. ${ }^{11}$ Leopold Damrosch offers a similar view of time in Blake as something that can be transformed imaginatively: 'the tiniest particle ... [which] contains the universe itself. ${ }^{\prime 2}$ Damrosch balances Blake against Frank Kermode's conception of the interval between the 'tick' and the 'tock' in The Sense of an Ending. Unlike Kermode, who perceives this interval as 'disorganized, unhumanized time,' Blake, in Damrosch's words, 'holds that it is precisely those interstitial moments that contain humanized reality, for they free us from history by liberating us into eternity' (351). And Mark Lussier, in a recent article for Nineteenth-Century Contexts, echoes Macey by suggesting that Blake offers 'an imaginative reconception' of time which relates it to natural rhythms of the body. ${ }^{13}$ Blake' s 'moment,' for these critics, constitutes an imaginative reworking of the moment to 
incorporate vast and minute units of time, both past and future, into one 'pulsation.'

It is important, however, to include space in this equation also. The massive vision which closes Book One of Milton also includes a vision of space in which 'every Space smaller than a Globule of Man's blood opens / Into Eternity of which this vegetable Earth is but a shadow' (29:21-22). And earlier, Blake alludes to the diamond, which, 'tho cloth'd / In rugged covering in the mine, is open all within, / And in his hallowd center holds the heavens of bright eternity' (28:36-3 8). For Blake, a prophetic, imaginative vision of time and space demands the capacity to hold both the microcosmic and the macrocosmic perspective together in some sort of paradoxical union. Time is a pulsation of an artery that contains an age; the tiny center of the diamond contains the heavens of eternity. And this paradox provides a clue to the connection between poetic vision, as presented in Blake's poetry, and the great horological inventions of the eighteenth century. ${ }^{14}$

To understand this connection, we must look at timepieces, not as philosophical metaphors, but as mechanical inventions made possible by the imaginative application of measurement, principles of physics, and precision engineering to solve specific problems. As such, they are products of the creative imagination in and of themselves, rather than mere sources of philosophical metaphors. When we look at the history of the inventions themselves, we find that horology has more in common with Blake than we might at first realize.

Let us begin with motive force. Whatever the Deists may have thought, no practical working horologist would have believed that a clock, once set in motion, could continue indefinitely. There is no such thing as perpetual motion, and horology is continually preoccupied with the task of supplying motive force, in the form of weights, or the tension of a mainspring, which keeps the mechanism moving. Furthermore, while horologists respected and relied upon the immutability of physical laws, they understood that these laws could not work without constant intervention. Clocks, to run smoothly, needed maintenance and repair. John Harrison (1775) devotes a significant portion of his study on the nature of chronometers to an analysis of the oils used on the pallets. Thomas Mudge, in his Thoughts on Means of Improving Watches (1799), characterizes the horologist's task as one of constantly reaching for eternal physical laws amid the inevitable presence of error, friction and decay:

The simple principles of all watches are, I apprehend, the same and perfect: the errors found in them are, therefore, not errors arising from the principles, but from the modification of those principles, and from imperfections inseparable 
from all mechanic operations ... The communicating [of] force through a train of wheels ... necessarily introduce[s] a great many errors arising from the imperfections of the mechanism, and the friction that is unavoidable, though executed in the most perfect manner; all which put together, produced a very unequal and irregular, instead of the supposed equal force. ${ }^{15}$

On the practical level of inventing and maintaining a timekeeper, be it watch, clock or marine chronometer, the horologist is not invoking a lifeless, predictable movement; like Blake's poet, he is dynamically engaging with the multitudinous accidents and errors of physical and mechanical existence, trying to make universal laws speak through them, and in spite of them.

But there is more to the story than this, for horological invention has always proceded from the dynamic interdependence of precision measurement and astronomy. During the seventeenth century, the two great horological inventions - the pendulum and the balance-spring escapement - came from astronomers: Galileo and Christian Huygens. But at the beginning of the eighteenth century, we find a rift emerging between these two perspectives: a rift caused not by philosophy but by economics, mercantilism and the problem of longitude.

At the turn of the century, both astronomers and philosophers were preoccupied with the problem of determining longitude at sea. While conventional navigation efforts enabled ships to find their latitude, no means existed for determining longitude, and European monarchs and merchants were growing increasingly anxious for a solution which would make sea travel less hazardous and more profitable. The solution ultimately lay with time: the ability to record the difference between the time at an established base and the time at sea. As Dava Sobel describes it in her account, the quest for a solution took two different paths: outward to the stars, or inward to the clock. ${ }^{16}$ Galileo, Cassini and Flamsteed attempted to find a solution based on astronomical patterns, either by tracing the moon's position among the stars, or by timing regular astronomical occurrences, such as the regular disappearance of specific moons behind Jupiter. Horologists such as Frisius, Huygens and Harrison believed that the solution lay in the creation of a precision timepiece, a marine chronometer, which, when set to the time at a specific longitude, would keep accurate time, enabling the ship to compare its own time with the standard time, and thus compute its longitudinal position.

Newton himself became involved in the controversy, and threw his influential support decisively behind an astronomic solution; no timepiece, he argued, could be so precise and so reliable that it could keep accurate time in spite of the motion of the ship and the variations in 
temperature and humidity that would affect the mechanism. Newton was to be proved wrong by John Harrison's invention of the marine chronometer. The solution to the longitude problem lay not in observing distant regularities but in anticipating and grappling with accidents and errors.

The invention of the marine chronometer highlights the double vision which informs horology as a trade. Time measurement, by its nature, involves integrating small units of duration - minutes and hours - into the complex movements of the celestial bodies, which determine our conceptions of solar or sidereal time. With the invention of an accurate marine chronometer, the ability to measure time periods of minute duration enabled one to locate one's longitudinal position on the globe. Like the diamond, which in its tiny center holds the heavens of bright eternity, the chronometer, in its minute precision, enabled one to conceptualize broad astronomical movements and calculate enormous distances.

Horology, then, by its very nature, bears strong resemblances to the poetic vision expressed in Milton and elsewhere in Blake's poetry. It is founded on a dynamic interaction between minute particulars and general principles: an interaction which requires constant vigilance and intervention. It is also founded on an acceptance of paradox; the oscillating movement of a pendulum or a balance wheel regulates the force of the weights, harnessing that force into the circular movement of the dial hands which registers the linear progression of time. 'Without contraries is no progression,' Blake claims in The Marriage of Heaven and Hell. Above all, horology rests upon the integration and inter-relationship of microcosmic and macrocosmic perspectives: the ability to measure the second as an accurate and meaningful unit of a day, and to use increasingly small subdivisions of time as a means of attaining global and astronomical perspectives. Eighteenth-century horologists possessed the conceptual apparatus necessary to perceive this fundamental paradox, and to perceive a universe in the tiniest pulsations. Their inventions were acts of ingenuity and imaginative power, expressed in mechanisms rather than in words.

Why, then, did Blake not see this connection or exploit it? His letters and records show no great awareness of, or sympathy with, horology as a trade or as an expression of genius. Although master watchmakers were concentrated in the Strand, close to the engraver James Basire, with whom Blake apprenticed, he seems to have had no great curiosity about them. Many reasons present themselves; obviously, Blake disliked the philosophical associations between horology and deism; furthermore, he was an engraver of books rather than of watch cases, and would have had no significant contact with them. 
But other reasons present themselves as well, reasons rooted in the growth of horology as a trade in the late eighteenth century. Horology was one of the first technologies to exploit the opportunities of division of labour; according to Leonard Weiss, the 'master watchmaker,' who had originally been responsible for the entire production of a watch, had, by the end of the century, become an overseer of specialized workers, and merely assembled and adjusted the finished clock. Rees's Cyclopaedia of 1819-20 lists twenty-one separate workmen employed on a watch, ranging from a wheel-cutter, who cut the motion wheels for the motion maker, to the cap-maker, the dial-plate maker, the case-maker, the escapement maker, the spring maker and the fusee-cutter: according to Weiss, 'many if not most of the artisans involved in watch-making were involved in simple, repetitive, semi-skilled tasks on specialized machines. ${ }^{17}$

While Blake might conceivably have felt some admiration and empathy for the inventor of a precision timepiece such as Harrison's marine chronometer, it is hard to imagine him feeling any sympathy for a business in which the insight and genius that made the product possible were so decisively removed from the act of manufacturing that product. The presence of the artist, together with the artist's ability to transform the mundane shell of the world, is central to Blake's cosmology; so much so that he avoided the standard technologies of printing for his great poems in favour of illuminated books which were hand-painted individually. Given this emphasis on the artistic presence, Blake would hardly have felt much empathy with the science of mass-produced timepieces.

Furthermore, the removal of the inventor's genius carries more sinister implications as well, implications that Blake evokes when he links the clock to the Satanic mills of human oppression. As long as one perceives the timepiece as the product of an individual act of inventive ingenuity, the timepiece provides a harmony between vast and minute perspectives, linking the precision of the minute hand to the broader movements of the sun and the stars. Once removed from the inventor, however, the timepiece suffers the fate of all human constructs in Blake's vision which are not continually re-energized by the prophetic or poetic imagination. The ticking of the clock ceases to point to a divine synthesis, and instead becomes a vehicle for tyranny and oppression. As Samuel Macey points out in The Dynamics of Progress, the clock in its new-found accuracy facilitated the Industrial Revolution, and its accompanying focus on time study, division of labour and oppressive reconceptualizations of work. ${ }^{18}$ With this division of labour, we find ourselves back in the fallen 'clock time' described by Northrop Frye, where past, present and future are no 
longer fused by an imaginative vision, and where the moments pass in a relentless sequence.

What we find, then, is not a pattern of influence in the traditional sense. Blake owed no particular debt to the main figures of the English horological revolution, although they may have a score to settle with Blake regarding their subsequent reputations. Instead, we have two distinct strands of creativity: the poetic creation of a visionary cosmology, and the mechanical creation of devices for measuring temporal duration. Although these two activities are often ideologically opposed, they nonetheless exhibit remarkable similarities. Both are founded on a lively interaction between the eternal and the mutable, between broad expanses of time and space on the one hand and minute particulars on the other. And both achieve this balance not by passively relying on external laws, but by actively interpreting this external reality through the exercise of individual creativity.

\section{GRANT CAMPBELL}

Dalhousie University

\section{Endnotes}

1 Joel Black, 'Introduction: Newtonian Mechanics and the Romantic Rebellion,' Beyond the Two Cultures: Essays on Science, Technology and Literature, ed. Joseph W. Slade and Judith Yaross Lee (Ames: Iowa State UP, 1990) 132.

2 William Blake, 'The Marriage of Heaven and Hell,' The Poetry and Prose of William Blake, ed. David Erdman and Harold Bloom (Berkeley: U of California P, 1982) Plate 8 , line 12. All subsequent quotations from Blake's writings are from this edition and, unless otherwise noted, will cite the plate number and line numbers.

3 Northrop Frye, Fearful Symmetry: A Study of William Blake (Princeton: Princeton UP, 1947) 46. All further references to Fearful Symmetry will cite the page numbers of this edition.

4 Samuel Macey, Clocks and fhe Cosmos: Time in Western Life and Thought (Hamden: Archon Books, 1980) 207.

5 The Poetry and Prose of William Blake 2.

6 The Poetry and Prose of William Blake 579.

7 David Erdman, Blake: Prophet Against Empire: A Poet's Interpretation of the History of His Own Times (Princeton: Princeton UP, 1954) 129, 158.

8 Donald D. Ault, Visionary Physics: Blake's Response to Newton (Chicago: U of Chicago $P, 1974) 1-3$.

9 The Poetry and Prose of William Blake 664.

10 For a survey of the development of the clock metaphor in English philosophy and literature during the eighteenth century, see Samuel Macey's essay, 'Clock 
Metaphor' in Encyclopedia of Time, ed. Samuel L. Macey (New York: Garland, 1994) 113-19.

11 Northrop Frye, 'Blake's Introduction to Experience,' Blake: A Collection of Critical Essays, ed. Northrop Frye (Englewood Cliffs: Prentice-Hall, 1966) 24.

12 Leopold Damrosch, Symbol and Truth in Blake's Myth (Princeton: Princeton UP, 1980) 103. All future references to Symbol and Truth in Blake's Myth will cite the page numbers of this edition.

13 Mark Lussier, 'Blake's Vortex: the Quantum Tunnel in Milton,' Nineteenth-Century Contexts 18 (1994): 274.

14 Many of these horological innovations in Britain arose from upheaval in France following Louis XIV's revocation of the Edict of Nantes in 1685, and the subsequent exodus of French Protestant craftsmen to England. Some of the more prominent inventions of the long eighteenth century include the dead-beat escapement, which increased accuracy by reducing recoil in the mechanism and became a feature of George Graham's precision regulator, and new forms of pendulum that resisted the effects of temperature variation, including Graham's quicksilver pendulum, and Harrison's gridiron pendulum. For a survey of the rise of precision in clock and watchmaking, see W.J.H. Andrewes, 'Clocks and Watches: The Leap to Precision,' Encyclopedia of Time, ed. Samuel L. Macey (New York: Garland, 1994) 123-27.

15 Thomas Mudge, 'Thoughts on the Means of Improving Watches; and more particularly those For the use of the Sea,' A Description with Plates of the Timekeeper Invented by the Late Mr. Thomas Mudge [1799] (London: Turner and Devereux, 1977) 5-6.

16 Dava Sobel, Longitude: The True Story of a Lone Genius Who Solved the Greatest Scientific Problem of His Time (New York: Walker, 1995).

17 Leonard Weiss, Watchmaking in England, 1760-1820 (London: Robert Hale, 1982) 36.

18 Samuel Macey, 'Great Britain and the Industrial Revolution,' The Dynamics of Progress: Time, Method and Measure (Athens: U of Georgia P, 1989) 139-54. 